\title{
ETYKA ZAWODOWA - JAK TO DZIAŁA?
}

\section{WSTĘP}

Pojęcie etyki życia gospodarczego jest zazwyczaj wiązane z normami i kodeksami zawierającymi katalog reguł zakazujących pewnych postępowań i oznajmiających, co należy czynić w określonych sytuacjach. „Zabraniająca” etyka jest łatwa do włączenia w myślenie ekonomiczne, które akcentuje dążenie do maksymalizacji indywidualnych korzyści, ponieważ ukazuje dodatkowy koszt angażowania się w zabraniane czyny oraz dodatkowe korzyści z przestrzegania norm etycznych, takie jak reputacja.

Korzyści i koszty postępowania etycznego włączone do kalkulacji ekonomicznej przybierają na ogół formę pieniężną (kary, utrata klientów lub dodatkowe przychody), co sprzyja bezrefleksyjnemu użytkowaniu norm etyki lub cynicznemu ich wykorzystywaniu w zależności od „wycen” przypisywanych poszczególnym działaniom. Do obu, skądinąd, różnych przypadków dochodzi, jeżeli wartości i uniwersalne zasady etyczne podlegają konkretyzowaniu w odniesieniu do pewnych specjalistycznych obszarów życia gospodarczego, np. rynków finansowych i zawodów tam wykonywanych. Budowanie szczegółowych kodeksów norm etyki zawodowej jest przedsięwzięciem społecznym $\mathrm{z}$ właściwymi dla społeczeństwa i grupy zawodowej zabezpieczeniami, które są podstawą wzmiankowanych wycen przypisywanych poszczególnym działaniom. Czy tak musi być? Czy etyka zawodowa działa poprzez rachunek korzyści i kosztów? Nie można wykluczyć, że niektórzy przedstawiciele zawodu w pewnych sytuacjach tak właśnie korzystają z etyki zawodowej. Przypadki fałszowania sprawozdań finansowych, manipulowania rynkami finansowymi, ukrywania i zniekształcania istotnych informacji, które występowały licznie w ostatnich dwudziestu latach, nie działy się w próżni etycznej. Symbol tych przypadków, Enron, miał kodeks etyczny i rozbudowany 
program etyczny, oparty na czterech wartościach, których skrót $\mathrm{RICE}^{1}$ sugerował nadrzędność wartości ekonomicznej ${ }^{1}$ (R. A. Prentice, 2007).

Celem artykułu jest poszukiwanie odpowiedzi na pytanie, jak działa etyka zawodowa, przy założeniu, że są ludzie, którzy bezrefleksyjnie lub cynicznie korzystają z istniejących już kodeksów etyki zawodowej, ale że są również przedstawiciele zawodu i otoczenia społecznego, którzy potrafią zrozumieć etykę i chcieć postępować etycznie w swoim zawodzie. Zatem poszukiwanie odpowiedzi na pytanie, jak działa etyka zawodowa, nastąpi w dwóch etapach. W pierwszym etapie zostanie omówiony proces ustanawiania norm etyki zawodowej, w drugim zaś proces podejmowania decyzji zawodowych jako decyzji etycznych. Efekt poszukiwań odpowiedzi na tytułowe pytanie zostanie przedstawiony w podsumowaniu.

\section{USTANAWIANIE NORM ETYKI ZAWODOWEJ}

Zawód, etyka i etyka zawodowa są pojęciami różnie definiowanymi, konieczne jest zatem określenie ich na potrzeby tego artykułu.

Powszechnie przez pojęcie zawód rozumie się każdą wyspecjalizowaną pracę, która wymaga odpowiedniej wiedzy, umiejętności i doświadczenia. Jednakże, używając określenia profesjonalizm w kontekście wykonywania zawodu, wyróżniamy szczególną wiedzę i umiejętności wymagające intensywnego kształcenia i praktyki, przypisywane niektórym zawodom. Tradycja niektórych, wyjątkowych zawodów, takich jak zawód lekarza i sędziego, oraz zawodów opartych na powołaniu - duchownego, nauczyciela ${ }^{2}$ wiąże się nie tylko ze specjalistyczną wiedzą, ale również ze szczególnym znaczeniem tych zawodów w życiu społecznym, wyrażanym przez oczekiwania społeczne. Od przedstawicieli zawodów oczekuje się nie tylko kompetencji, ale również wysokiego poziomu moralnego przekraczającego przeciętną normę bycia dobrym obywatelem przestrzegającym prawa. Powstała więc tradycja nadawania grupom wyróżnionych zawodów specjalnego statusu autonomii zawodowej - pod warunkiem spełniania szczególnych oczekiwań społecznych. Ten stan rzeczy obliguje przedstawicieli zawodu do sprostania zaufaniu społecznemu w dwóch obszarach: profesjonalizmu i etyczności.

Etyka jest również różnie definiowana. $Z$ jednej strony, jest częścią filozofii, która ma odmienne niż nauka sposoby rozumienia. Inaczej niż nauka zmierzająca do odkrycia zależności występujących w rzeczywistości i ich wyjaśnienia, etyka

${ }^{1}$ RICE (Respect, Integrity, Communication, Excellence) wymawia się podobnie jak rise (wzrost, awans).

${ }^{2} \mathrm{~W}$ języku angielskim Profession pochodzi od profess - głosić, co wskazuje na duchownych i nauczycieli. W języku niemieckim Beruf - również ma podobny źródłosłów, przy czym oznacza zarówno zawód, jak i powołanie. 
jest dążeniem do mądrości w formułowaniu odpowiedzi na pytanie: jak żyć? Jest to więc refleksja nad moralnymi stanami faktycznymi, systematyzacja wartości moralnych, odkrywanie i interpretacja zasad etycznych, porządkujących życie człowieka w otoczeniu społecznym. Tak zdefiniowana etyka jest abstrakcyjnie oddzielona od praktyki zawodowej i od każdej innej działalności człowieka, przede wszystkim ze względu na jej aksjologiczny aspekt. Oznacza to, że w dążeniu do odpowiedzi na pytanie: jak żyć? etyka opiera się na aksjomatach o naturze człowieka, sensie i celu jego życia. Są to zdania pierwsze, które nie mogą być wyprowadzone $\mathrm{z}$ bytu, ponieważ stanowią one przesłanki wnioskowania o tym, jak być powinno (D. Hume, 1952).

Etyka zawodowa stanowi jedną z wielu etyk szczegółowych, które zajmują się badaniem zagadnień etyki ogólnej w konkretnych obszarach życia człowieka. Próbuje zastosować ogólne zasady i pojęcia moralne do praktycznych zagadnień danego zawodu. W tym miejscu trzeba zauważyć, że nie we wszystkich, potocznie określanych, zawodach występują szczególne problemy etyczne. Jedynie w takich zawodach, które określa się jako zawody zaufania publicznego, pojawiają się konflikty moralne i dylematy moralne, które wymagają refleksji i odpowiedzi normatywnej, tj. regulującej postępowanie przedstawiciela zawodu.

W zawodach zaufania publicznego, np. lekarza i sędziego, występują sytuacje wymagające rozstrzygnięć między różnymi wartościami moralnymi, np. między życiem a prawdą, z którymi nie spotykają się ludzie wykonujący inne zawody. Powstają wówczas dylematy moralne, stanowiące konkretny wymiar konfliktu moralnego między wartościami moralnymi. W wielu zawodach powstają dylematy o podłożu moralnym, w których źródłem są różne interesy prywatne w sprzeczności z interesem społecznym. Takie dylematy nie powinny być trudne do rozstrzygnięcia dla osób o wysokim poziomie moralnym ${ }^{3}$ (P. Aszyk, 1998). Trudno jednak wykluczyć możliwość zróżnicowania nie tylko poziomu moralnego, ale również przekonań i postaw członków grupy zawodowej, darzonej zaufaniem społecznym. Tradycja stworzyła silne poczucie więzi z grupą, bliskość stosunków z innymi członkami i subiektywne poczucie identyfikacji z grupą zawodową (P. Sztompka, 2002). Powstają one w wyniku istnienia wartości i norm, które spajają grupę. Nadanie jej autonomii, w celu ochrony interesu publicznego, jest źródłem dodatkowego dylematu, wymagającego rozstrzygnięć między indywidualnymi wartościami hedonicznymi i ekonomicznymi, grupowymi wartościami lojalności i solidarności oraz uniwersalnymi wartościami moralnymi, cenionymi

\footnotetext{
${ }^{3}$ W świetle koncepcji L. Kolberga (1981) wysoki, tzw. postkonwencjonalny, poziom moralny osiągają ludzie, którzy przyjmują perspektywę otwarcia się na innych ludzi i zainteresowania ich losem. Potrafią dokonywać uniwersalnych ocen i wyborów moralnych. Ludzie o niższym poziomie moralnym podporządkowują się interesom grupy lub społeczeństwa z perspektywy interesu własnego.
} 
przez społeczeństwo. $Z$ tych powodów nie wystarczy indywidualne sumienie i cnoty niektórych przedstawicieli zawodów zaufania publicznego. Niezbędne okazuje się ustalanie norm etyki zawodowej jako społecznie akceptowanych reguł postępowania (A. Anzenbacher, 2008), przyjmowanych bez przymusu i realizowanych przez członków zawodu. Normy etyki zawodowej są zatem fenomenem społecznym. Składają się z nich kodeksy, które charakteryzują, jak dana grupa zawodowa postrzega swoje obowiązki społeczne, jaki jest ich wymiar etyczny i stosowalność.

Ustanawianie norm etyki zawodowej ma długą tradycję nie tylko w zawodzie lekarza, sędziego czy rycerza (żołnierza). Również zawody kupieckie i bankierskie mogły oczekiwać społecznej aprobaty pod warunkiem samoregulacji. Powstające wraz z rozwojem gospodarki rynkowej nowe rynki: ubezpieczeń, papierów wartościowych itp. były spontanicznie organizowane za pomocą reguł postępowania maklerów, dilerów, brokerów, a później także księgowych, biegłych rewidentów czy analityków finansowych (E. G. Furubotn, R. Richter, 1997). Kodeksy postępowania w tych zawodach są świadectwem argumentacji etycznej i dyskursu, prowadzącego do konsensusu możliwego w danym czasie i w danej społeczności.

Normy etyki zawodowej stanowią przede wszystkim doświadczenie wynikające $z$ tradycji judeochrześcijańskiej, zawartej w dekalogu i złotej regule postępowania etycznego, $z$ koncepcji etycznych starożytnych filozofów greckich i prawa rzymskiego. „Czyń tak, jak chciałbyś, aby wobec ciebie czyniono”, „po pierwsze nie szkodzić”, „umów należy dotrzymywać” - takie reguły były przekazywane między pokoleniami aż do współczesności. Zasada podwójnego skutku, stosowana w średniowieczu (Św. Tomasz z Akwinu, 1970), jest nadal niezastąpiona $\mathrm{w}$ rozwiązywaniu dylematów moralnych.

Zawodowe dylematy uczestników rynków finansowych nie zawsze mogą być rozstrzygane za pomocą takich zasad. Szczególne znaczenie rynków finansowych i wysoce specjalistyczna działalność ich animatorów wymagają połączenia specjalistycznej wiedzy zawodowej, znajomości konkretnych sytuacji zawodowych oraz wiedzy z zakresu etyki ogólnej i szczegółowej. Eksperci z tych różnych dziedzin przedstawiają argumenty zgodne $\mathrm{z}$ ich kompetencjami zawodowymi oraz poglądami etycznymi. Nieunikniony jest zatem pluralizm stanowisk i argumentów, który wymaga dyskusji w rzeczowej atmosferze, przebiegającej w „lustrze” społecznym. Nie zawsze prowadzi to do uzgodnienia normy postępowania zawodowego, zwłaszcza w sytuacji konfliktu moralnego. Natomiast dylematy o podłożu moralnym, wyrażające się jako konflikty interesów prywatnych i społecznych, mogą być rozstrzygane za pomocą nowożytnych koncepcji sprawiedliwości rozdzielczej, sformułowanej przez Arystotelesa (1996). Koncepcje te, akcentując autonomię wolnego podmiotu moralnego, ustalają deontologiczną zasadę jednakowej wolności dla wszystkich osób, co implikuje uwzględnienie wszystkich interesów, 
tak żeby w konkretnej sytuacji zawodowej postępowanie było korzystne w sensie rozdzielczym dla wszystkich ${ }^{4}$ (A. Anzenbacher, 2008, s. 129). Jako przykład, rozważmy zastosowanie superszybkich komputerów do realizowania błyskawicznych zleceń kupna lub sprzedaży (flash orders), dla których wykorzystuje się informacje o cenach w ułamku sekundy, szybciej, niż zrobiłby to człowiek. Powstaje dylemat: czy interesy wszystkich uczestników rynku giełdowego są sprawiedliwie uwzględniane? Uprzywilejowani są inwestorzy posiadający te urządzenia elektroniczne i giełda, zarabiająca na prowizji od obrotu. Natomiast inwestor detaliczny jest w gorszej sytuacji, składając niebłyskawiczne zlecenia, choć korzysta na zwiększonej płynności obrotu. Maklerzy tradycyjnie gwarantowali równy dostęp do informacji i uczestniczenia $\mathrm{w}$ transakcjach. Innowacje technologiczne stworzyły nową sytuację, która wymaga uregulowania (A. van Duyn, 2009).

Przykład ten pokazuje, że w dyskursie nad unormowaniem sposobu składania zleceń powinni uczestniczyć nie tylko eksperci zawodowi i etycy, ale również przedstawiciele różnych grup interesu, ażeby możliwe było ustanowienie normy chroniącej interes publiczny, a jednocześnie akceptowanej przez grupę zawodów obsługujących giełdę. Oznacza to, że normy zawodów zaufania publicznego powinny spełniać wysokie oczekiwania społeczne. $\mathrm{W}$ przeciwnym razie zaufanie to może być wycofane i przeniesione do innych segmentów rynków finansowych. Przedstawiciele zawodów zaufania publicznego, uczestniczący w stanowieniu norm zawodowych, powinni szczerze i otwarcie określać sytuacje specyficzne dla ich zawodu, które należy uregulować.

Kodeksy, stanowiące zbiór wartości i zasad etycznych oraz wypracowanych na ich podstawie reguł etyki zawodowej i standardów zawodowych, spełniają swą funkcję chronienia interesu społecznego, jeżeli są konkretne, wykonalne i stosowane w praktyce. Stosowanie norm etyki zawodowej wymaga wspólnego zaangażowania osób i grup w procesie podejmowania decyzji zawodowych w aspekcie etycznym.

\section{PODEJMOWANIE ZAWODOWYCH DECYZJI W ASPEKCIE ETYCZNYM}

Ustanowione normy etyki zawodowej są zobowiązaniem grupy zawodowej do ich przestrzegania. Wyrazem zaufania społecznego jest nadanie grupie autonomii wraz z uprawnieniem do egzekwowania wysokiego statusu zawodowego. Kredyt zaufania, którego udziela społeczeństwo, nie jest bezwarunkowy. W Konstytucji

${ }^{4}$ Oprócz deontologicznych systemów etycznych, w których został sformułowany problem sprawiedliwości (Arystoteles, 1996; I. Kant, 1984; J. Rawls, 1994), można również rozważać argumenty utylitarystyczne (J. Bentham 1958) i klasyczne argumenty prawa naturalnego (Św. Tomasz z Akwinu, 1970; J. Locke, 1992; D. Hume, 1952). 
Rzeczypospolitej Polskiej ustalono, że: „można tworzyć samorządy zawodowe, reprezentujące osoby wykonujące zawody zaufania publicznego i sprawujące pieczę nad należytym wykonywaniem tych zawodów w granicach interesu publicznego i dla jego ochrony" (art. 17, Konstytucja RP z 1997 r.).

Stosowanie się do norm etyki zawodowej polega na podejmowaniu decyzji zawodowych zawsze $\mathrm{w}$ ramach osobistego zaangażowania sumienia, rozumu i woli konkretnej osoby. $Z$ badań nad procesem powstawania tych decyzji wynika, że oceny, wybór i działanie przebiegają stopniowo w czasie. Sekwencyjność procesu decyzyjnego przedstawiona została przez T. M. Jonesa w modelu czteroetapowym, który jest adaptacją opisu procesu decyzyjnego, dokonywanego przez J. Resta (1986).

Pierwszy etap polega na identyfikacji dylematu moralnego w danej sytuacji; ustaleniu, jakie osoby i ich interesy znajdują się w zasięgu tej sytuacji. Wrażliwość na innych wymaga dojrzałości moralnej osiąganej na konwencjonalnym stopniu rozwoju moralnego (L. Kolberg, 1981). Osoby, które wykonując zadania zawodowe, mechanicznie i bezrefleksyjnie stosują normy i standardy zawodowe, nie identyfikują problemu moralnego. Co więcej, mogą używać tych norm jako swoistej licencji moralnej dla działań nieetycznych (D. M. Cain i inni, 2005).

Jones wprowadził do swego modelu pojęcie moralnej intensywności (moral intensity), która oznacza stopień znaczenia aspektu moralnego dla osoby podejmującej decyzję. Już pierwszy etap procesu decyzyjnego pokazuje, że moralna intensywność w identyfikacji dylematu moralnego może być wysoka lub niska.

Drugi etap procesu decyzyjnego polega na dokonaniu oceny moralnej czynu, który został wstępnie rozpoznany jako czyn wymagający zaangażowania etycznego.W zależności od oceny podjęta zostaje decyzja,jakie działanie należy wykonać, aby rozwiązać dylemat moralny (T. Jones i inni, 2003). Decyzje tę podejmą te osoby, których wysoka intensywność moralna umożliwia pogłębianie refleksji etycznej, rozważanie różnych argumentów i jasne określenie, co jest etyczne w danej sytuacji, a co nie jest etyczne. $Z$ badań wiadomo, że osoby, które posiadają tę cechę, mogą dopuszczać się zupełnie różnych czynów (J. Rest, 1978; S. J. Thomas i inni, 1986). Dlatego kolejnym etapem procesu decyzyjnego jest wzbudzenie w sobie i utrwalenie moralnej intencji działania zgodnego z powziętym zamiarem. Powstanie intencji moralnej jest aktem wyboru rozwiązania dylematu moralnego ze względu na wartość zawodowej uczciwości, niezależnie od strat finansowych i reakcji otoczenia. Wysoka moralna intensywność kieruje wówczas ku ostatniemu etapowi procesu decyzyjnego - podjęciu konkretnego działania, zgodnego z dokonaną oceną moralną i powziętą intencją.

Moralna intensywność może być pobudzana lub tłumiona ze względu na uczestnictwo w grupie zawodowej. $Z$ jednej strony, społeczne zobowiązania sformułowane w kodeksach etycznych mogą dostarczać bodźców do dojrzewania 
moralnego. Dzieje się tak, jeżeli kodeksy etyczne są przestrzegane, systematycznie analizowane i aktualizowane oraz jeżeli w grupie są osoby o wysokim autorytecie, które stanowią wzorzec postępowania i pełnią przywództwo etyczne. $Z$ drugiej strony, grupy zawodowe wykazują silne poczucie więzi wśród członków, oparte na wartości lojalności i solidarności dla grupy.

Lojalność jest wartością, której znaczenie odczytuje się w kontekście celu, do którego się nawiązuje. Najczęściej, lojalność oznacza wierność obowiązkom wynikającym z przynależności do grupy oraz posłuszeństwo względem jej reguł (M. Ossowska, 1985). Lojalność w grupach zorganizowanych hierarchicznie polega na lojalności pracowników wobec przełożonych. W grupie zawodowej złożonej z równych sobie członków lojalność polega na manifestowaniu jednolitości indywidualnych postaw, czynów i wartości preferowanych przez grupę. W tym znaczeniu lojalność oznacza wierność przyjętym przez grupę regułom i wywiązywanie się z przyjętych wobec grupy zobowiązań. Przynależność do grupy jest wyrazem obowiązku akceptowania jej reguł i zadań, choć niekoniecznie tych, które są formalnie akceptowane. Grupa jest trwała, jeżeli jej członkowie darzą się zaufaniem, dotyczącym oczekiwania wzajemnych korzyści wynikających z członkostwa. Te zaś można osiągnąć, jeżeli członkowie grupy są względem siebie lojalni. Nie jest to zatem lojalność podwładnego wobec przełożonego, lecz lojalność wzajemna, manifestująca się w akceptacji członkostwa zarówno wobec grupy, jak i wobec otoczenia społecznego.

Lojalność należy do tych wartości tworzących więź moralną, która może służyć do różnych celów. Grupy zawodowe cenią lojalność ze względu na jej znaczenie jako spoiwa, zapewniającego trwałość grupy. Zaufanie, którym obdarzają się członkowie grupy, ma charakter ekskluzywny, zatem lojalność może znaleźć się na przeciwnym biegunie wobec donosicielstwa, jeżeli służy interesowi grupy odmiennemu od interesu publicznego. Potoczne „zamiatanie pod dywan” czynów niegodnych zawodu i naruszających interes publiczny może być cenioną przez grupę lojalnością, natomiast ujawnianie tych czynów może zostać uznane za przejaw nielojalności wobec grupy. Jednocześnie, z punktu widzenia interesu publicznego lojalność wobec grupy oznacza zaburzenie zaufania społecznego wobec grupy. Wyraźne jest zatem, że grupy zawodów zaufania publicznego stają przed problemem zdefiniowania lojalności w podwójnej perspektywie: po pierwsze, w perspektywie tożsamości grupowej związanej z lojalnością wobec grupy, oraz po drugie, w perspektywie zaufania społecznego wiążącego się z lojalnością wobec obowiązków społecznych.

Podobnie przedstawia się znaczenie drugiej wartości, która tworzy więź grupy, solidarności. Ujawnia się ona $\mathrm{w}$ intensywności i trwałości powiązań między przedstawicielami zawodu a grupą, z której celami identyfikują się. W kręgu solidarności tożsamość osoby i grupy silnie pokrywają się, co powoduje, że człon- 
kowie grupy wykazują zbieżność przekonań i interesów lub zgodność działań. $\mathrm{W}$ ujęciu bytowym wyraża się to $\mathrm{w}$ trosce o interesy grupy i $\mathrm{w}$ działaniach na rzecz grupy oraz jej członków. Natomiast w sensie powinnościowym solidarność jest obowiązkiem utożsamiania interesu własnego $\mathrm{z}$ interesem grupy, a nawet przedkładania interesu grupy nad interes własny (B. Sutor, 1994; P. Sztompka, 2002). W pierwszym znaczeniu solidarność polega na współpracy i wzajemnej pomocy służącej wzajemnym korzyściom członków grupy. Natomiast solidarność jako obowiązek jest zbliżona do troski o dobro wspólne grupy. W tych ujęciach wyrażone jest, że grupa zawodowa zaufania publicznego staje przed problemem zdefiniowania dobra wspólnego w podwójnej perspektywie: po pierwsze, w perspektywie tożsamości grupy związanej z solidarnością wzajemną członków oraz po drugie, w perspektywie odpowiedzialności za nieredukowalne dobro wspólne. W pierwszym przypadku solidarność służy zaufaniu w grupie, natomiast w drugim przypadku służy zaufaniu społeczeństwa wobec grupy.

Kluczowy dla obu wartości jest problem interpretacji zaufania. Jest to pojęcie wieloznaczne, stosowane w różnych znaczeniach: psychologicznym, socjologicznym, ontologicznym, etycznym i nawet ekonomicznym. Służy ono jako wartość zwieńczająca i łącząca w całość różne wartości instrumentalne, takie jak lojalność i solidarność. Tak przedstawiana jest jego rola w koncepcji kapitału społecznego R. Putmana. Jeżeli zaufanie obejmuje tylko grupę, to kapitał społeczny składa się z „właściwości życia społecznego - sieci, norm i zaufania, które ułatwiają współpracę i koordynację w celu wzajemnej korzyści” (Putman, 1997). Ten kapitał społeczny Putman później określił jako kontraktowy i ekskluzywny (bonding social capital), ponieważ sieci, normy i zaufanie realizowane są za pomocą lojalności grupowej (Putman, 2000). Natomiast jeżeli „zasoby kapitału społecznego w postaci zaufania, norm i sieci ulegają samowzmocnieniu i kumulacji, (to) koła prawości przynoszą rezultaty w postaci społecznej równowagi i wysokiego poziomu współpracy, zaufania, wzajemności, obywatelskiego zaangażowania i zbiorowego dobrobytu" (Putman, 1993). W tej wersji kapitał społeczny ma charakter pomostowy, inkluzywny (bridging social capital), jako źródło społecznego dobrobytu.

Lojalność i solidarność grupy zawodowej mogą służyć interesom grupy lub interesowi publicznemu w zależności od tego, którą z perspektywy, przyjmuje grupa: ekskluzywną czy inkluzywną. Perspektywa ekskluzywna ujawnia przede wszystkim bytowy sens lojalności i solidarności jako spoiwa tworzącego trwałość grupy. Sens ten ma długą tradycję wywodzącą się z plemiennej wspólnotowości, przejawiającą się współcześnie w konformizmie grupowym wyborów i działań ludzkich. W aspekcie powinnościowym oznaczałoby to zdominowanie grupy zawodowej przez osoby, które nie osiągają postkonwencjonalnego poziomu rozwoju moralnego. Rozważają one swoje wybory i postępowanie z perspektywy interesu 
własnego związanego z uczestnictwem w grupie zawodowej. Dominowanie takich postaw i czynów jest faktem empirycznym.

To stanowi źródło dylematu dla tych członków grupy zawodowej, którzy reprezentują wysoką moralną intensywność, ale pozostają w mniejszości. W sytuacjach, gdy zaufanie i interes społeczny są poważnie zagrożone, mogą stanąć wobec dylematu: ujawnić niekorzystną dla społeczeństwa praktykę zawodową czy odejść z zawodu. Przypadek amerykańskiego analityka, który w prywatnej poczcie elektronicznej cynicznie informował, iż jego rekomendacje wprowadzają inwestorów w błąd, może świadczyć o negatywnej selekcji w zawodach wykonywanych na rynku finansowym w Stanach Zjednoczonych (R. A. Prentice, 2007). Można hipotetycznie twierdzić, że $\mathrm{z}$ dwóch możliwości: wychodzenia $\mathrm{z}$ grupy zawodowej, która nie podtrzymuje wysokich standardów, lub unikania wchodzenia do takiej grupy osób o dojrzałej moralności, ponieważ nie miałyby szansy funkcjonować jako „istotni inni”(significant others) ${ }^{5}$, bardziej prawdopodobna jest druga możliwość. Wówczas można twierdzić, że wzmocnienie moralnej intensywności będzie zależało od otoczenia społecznego, które odczuwając niekorzystne skutki pewnych praktyk zawodowych, „uwolni” grupę od autonomicznej regulacji standardów zawodowych, zastępując kredyt zaufania regulacjami prawa stanowionego, zabezpieczonymi przymusem.

\section{ZAKOŃCZENIE}

W etyce zawodowej, pojmowanej jako empiryczny fenomen wyrażający napięcie pomiędzy indywidualnymi wartościami a oczekiwaniami społecznymi, ścierają się dwa nurty. W jednym nurcie broniona jest autonomiczność grupy zawodowej w taki sposób, że odpowiadając na oczekiwania społeczne, chroni się autonomię osoby i wysoki status wykonywanego zawodu. Ta strategia wymaga długookresowego trudu dążenia do statusu zawodu zaufania publicznego, który nie jest dowolnym przywilejem wynikającym z profesjonalizmu, ale wartością konieczną do uzyskania akceptacji społecznej. W długim okresie tak działająca etyka zawodowa mogłaby stać się samoistną wartością. W drugim nurcie praktyka zawodowa jest skoncentrowana na doraźnym i mechanicznym przestrzeganiu reguł i standardów zawodowych, co wydaje się przeważać w zawodach uprawianych na rynkach finansowych. Szybki rozwój tych rynków ujawnia nowe sytuacje, które nie są ujęte w kodeksach etyki zawodowej. Skłania to mniej dojrzałych przedstawicieli zawodu do taktyki przestrzegania tylko istniejących regulacji i stwarza pokusę

${ }^{5}$ Pojęcia istotnych innych i nieistotnych innych zostały wprowadzone do analizy stosunku jednostki i zbiorowości przez G. H. Meada (1975). 
do wykorzystywania luk w normach zawodowych. Skandale i afery na amerykańskim rynku finansowym w zawodach biegłego rewidenta, maklera, analityka finansowego, pośrednika finansowego kończą się zazwyczaj uchwaleniem nowego prawa, ograniczającego swobodę wykonywania tych zawodów. Skutkiem tego jest ułatwienie warunków wejścia do zawodu, ponieważ grupa zawodowa traci zaufanie społeczne, które zostaje przesunięte do wymiaru sprawiedliwości, działającego ex post konkretnej praktyki jako indywidualnego przestępstwa. W artykule zwrócono uwagę na znaczenie przeciętnego poziomu moralnego osób wykonujących zawody zaufania publicznego, który może być doskonalony, o ile grupa zawodowa rozumie swoje powinności wobec otoczenia społecznego.

\section{PROFESSIONAL ETHICS - HOW DOES IT WORK?}

SUMMARY

The aim of paper is to seek the answer to the question, how professional ethics acts as an empirical phenomenon. The starting point is an assumption about the natural ethical disposition of mankind. In different professional situations moral conflicts and dilemmas appear. To resolve them, moral maturity of the person is necessary, and group - oriented building of social trust. In the paper were described: regulation of professional conduct, forming professional standards, and the process of making ethical professional decisions. Moral intensity, framing of professional group and social expectations are complementary elements of the social process in which professional ethics acts. 